\title{
Brugerinvolvering $\mathbf{i}$ design af
}

\section{læreprocesser}

- refleksioner over et større

forsknings- og udviklingsprojekt

\section{Niels Henrik Helms}

\section{Lektor, direktør}

Syddansk Universitet

nhh@knowledgelab.sdu.dk

\section{Simon B. Heilesen}

Lektor, mag.art.

Roskilde Universitet

simonhei@ruc.dk
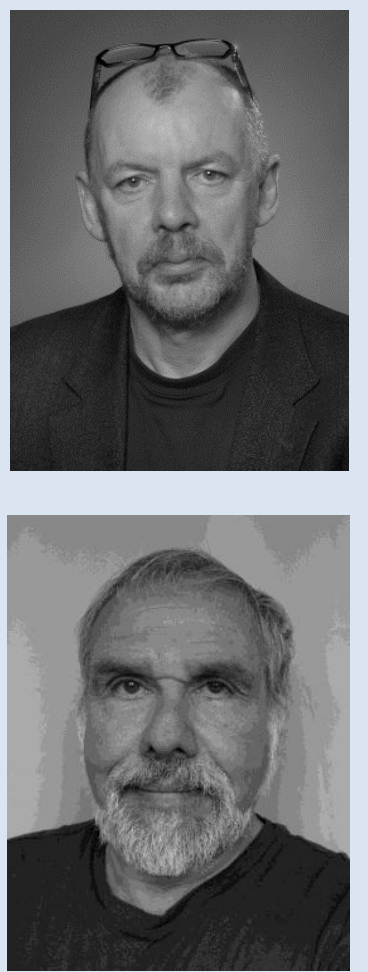
Niels Henrik Helms er lektor ved institut for Litteratur, Kultur og Medier, Syddansk Universitet. Han er også direktør for Knowledge Lab sammesteds. Han arbejder med forsknings- og udviklingsprojekter inden for innovation, læring og it. Lige nu især samspillet mellem erhvervsuddannelser og innovation gennem netværksdannelse. Forskningsmæssigt især materialitet og læring.

Simon Heilesen er lektor ved Institut for Psykologi og Uddannelsesforskning, Roskilde Universitet. Han er knyttet til Unipæd (Universitetspædagogisk Efteruddannelse), hvor han arbejder med Akademisk IT, dvs. forskning, formidling og undervisning med inddragelse af digitale medier. Aktuelt arbejder han med læringsrum (fysiske og virtuelle) og med digital alfabetisme i forbindelse med uddannelses-og velfærdsteknologier. 


\section{Resumé}

Innovationsprojektet ELYK har gennem forsøg med brugerdrevne, eksperimentelle metoder udviklet forskellige e-læringskoncepter. Underliggende disse aktiviteter har der været arbejdet med forskellige metoder og været foretaget begrebsafklaringer. Artiklen introducerer projektets vigtigste metodiske nyskabelser samt de overvejelser om brugere, design og netværk, der har dannet baggrund for dem. Vi hævder, at "brugeren" er en konstruktion, der må forstås i en given aktivitet og sammenhæng, som rammesættes af samspillet mellem virksomheder, myndigheder og vidensinstitutioner. Begrebet "didaktisk design" diskuteres ud fra betragtningen, at der i design-aktiviteter er behov for at medtænke og involvere forskellige tilgange samt forskellige kompetencer hos aktørerne. "Design thinking" inddrages for at pointere, at design er en eksplorativ, dialogisk og til dels også emotionel og intuitiv proces. Disse overvejelser fører frem til Firefelt-modellen, en metadesign-model, der har været anvendt som grundlag for alle ELYK-udviklingsforsøg. Afslutningsvis anskues ELYK-projektet i et bredere perspektiv som afsæt for at reflektere over, hvordan en e-læringsdidaktik kan tænkes i forhold til nye kommunikations- og samarbejdsformer - en første skitse til en netværksdidaktik. De læringsmuligheder, der ligger i netværk, transformeres ikke til læring uden en forståelse for såvel læringsmuligheder og -potentialer, som hvordan potentialerne kan realiseres i forhold til de skiftende kontekster, som mennesker indgår i.

\section{Abstract}

The ELYK innovation project has developed several e-learning concepts by means of user-driven, experimental methods. Underlying these activities, work has been carried out developing methods and defining key concepts. This article introduces both the key methods of the project and the reflections on the concepts "users", "design", and "network" that have helped shape them. We argue that the "user" is a construction to be understood in terms of activities and contexts framed by the interrelations of business, authorities, and knowledge institutions. The concept "didactic design" is problematized, arguing that when designing, the approaches and competences of all actors need to be actively involved. "Design thinking" is drawn upon so as to emphasize that designing is an explorative, dialogical, and also emotional and intuitive process. These reflections have led to the Quadrant Model, a meta-design model that has grounded all ELYK design experiments. By way of conclusion, the ELYK-project is considered in a wider perspective as a starting point for reflecting on how to relate elearning didactics to new ways of learning and collaborating in networks. The learning potentials of networks are not transformed into learning 
without an understanding of how the potentials can be implemented in the changeable contexts of human endeavour.

\section{Introduktion}

Denne artikel tager udgangspunkt i forsknings- og udviklingsprojektet "ELYK" (E-læring, Yderområder og Klyngedannelse; 2009-2012, http://elyk.dk), et forsknings- og udviklingspartnerskab mellem Roskilde Universitet, Syddansk Universitet, University College Sjælland og University College Syd. Projektet har modtaget støtte fra Den Europæiske Fond for Regionaludvikling og fra Erhvervs- og Byggestyrelsen. ELYK har været et forskningsbaseret innovationsprojekt, som gennem forsøg med brugerdrevne og eksperimentelle metoder har udviklet nye elæringskoncepter i forhold til arbejdsliv, netværksdannelser og efter- og videreuddannelse. Projektet har dermed også givet anledning til en række diskussioner af metoder, modeller og den eventuelle sammenhæng mellem disse. Det følgende er forfatternes forsøg på at tegne et kort over det landskab, som projektet har udviklet.

\section{Brugeren i centrum - men hvem er brugeren?}

Brugerdreven innovation er blevet svaret på mange af de udfordringer, som samfundet står overfor. Det kræver selvfølgelig en identifikation: Hvem er brugerne? Og hvorfor har de dette særlige innovative potentiale? Vil de overhovedet have denne rolletilskrivning? Det enkle svar på hvem brugeren er i en videndelings- eller læringssituation kunne være "deltageren" eller "eleven". Men det er en grundantagelse i nærværende projekt, at det ikke er muligt at isolere brugeren, hverken fra den kontekst han eller hun optræder i, eller fra de relationer med andre som brugeren indgår i. Brugeren er således en relativ konstruktion, der konstituerer sig gennem den måde, som vedkommende indgår i fx en udviklingsproces; altså hvilken rolle, der tilskrives ham eller hende. Om brugeren bliver innovativ, eller snarere hvorvidt vi kan øge sandsynligheden af, at han eller hun indgår som en innovativ forandrende ressource, er bestemt af, hvorvidt der laves et udviklingsmæssigt design, som muliggør dette.

For overordnet at forstå det komplekse samspil mellem de mange aktører, som indgår i det typiske ELYK-udviklingsprojekt, har vi valgt at skabe en overordnet teoretisk ramme ud fra en nyfortolkning af triple helixbegrebet, hvor quadruple helix-begrebet med dets inddragelse af "brugeren" benyttes som afsæt.

Triple helix-modellerne (Etzkowitz, 2002) har været anvendt til at beskrive innovation, særligt i forbindelse med udvikling af politikker på området. Der er tale om en spiralformet model, som beskriver det gensidige samspil mellem domæner bestående af myndigheder, videnskab og virksomheder, 
og hvor oversættelseszoner muliggør strukturelle koblinger mellem domænernes konkrete aktører (Helms, 2009). Modellerne beskriver ikke, hvordan samspillet organiseres, og de antager implicit, at alle relationer er symmetriske. Vi vil imidlertid hævde, at der typisk er tale om asymmetriske relationer, fordi magtforhold og former for viden aktørerne imellem er forskellige. I brugernes univers er viden situeret, lokal, praktiskproduktiv i højere grad end teoretisk-videnskabelig, og den er ofte bundet til mundtlighed. For at skabe videndeling og uformel læring er det nødvendigt på tværs af de strukturelle relationer at skabe en dialog, som transcenderer rationaliteter og videnformer. Til det formål er det nyttigt at se på den nyere helix-teoriudvikling, som medtænker brugeren som et fjerde domæne.

I quadruple helix-modeller indgår menige borgere som aktive medskabere af ny viden og nye produkter. Der er ikke tale om én model, men om forskellige tilgange spændende fra en triple helix, hvor brugernes erfaringer blot medtænkes og til en, hvor brugerne indgår som innovatorer på linje med myndigheder, vidensinstitutioner og virksomheder (Arnkil, Järvensivu, Koski \& Piirainen, 2010).

De fire domæner er her bredt defineret, og i en given anvendelse af quadruple helix-modellen er det nødvendigt at præcisere dem. Således skal begrebet "bruger" (eller "borger") forstås i en helhed af konkrete aktiviteter og en socio-kulturel sammenhæng, som gerne udgøres af komplekse afhængigheder. Modellens forskellige domæner opfattes gerne som afgrænsede enheder, der nok i interaktion kan have samme objekt, men hvor der er forskelle i betydningen af dem. Ud fra en virksomheds perspektiv kan en bruger være kunde eller medarbejder. For myndighederne er han borger eller klient, og i forbindelse med vidensinstitutionen måske studerende, forsker eller informant. Endvidere har brugeren flere dimensioner: Håndværkeren, som videndeler i det elektroniske netværk, er såvel erhvervsrepræsentant, som kunde i andre virksomheder, klient hos kommunen, og lærende i sammenhæng med en formaliseret efteruddannelse. For at visualisere disse komplekse relationer har vi udviklet en ny udgave af triple helix-modellen, hvor brugeren ikke er en fjerde part i quadruple helix forstand, men bliver den fælles kode som gør, at de involverede aktører har et fælles anliggende. Dette fælles anliggende er netop, at alle taler om brugere som et begreb, der udtrykker en fælles, men ikke identisk nyfortolkning af relationerne borger/myndighed, virksomhed/aftager, studerende/vidensinstitution. 


\section{myndighed}

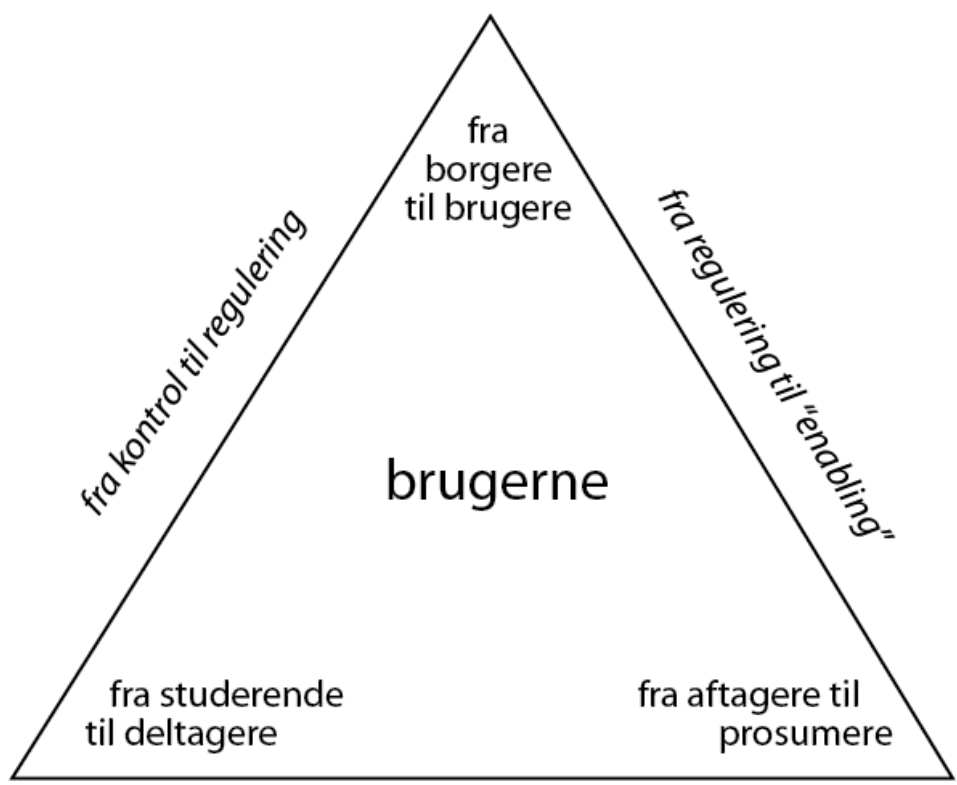

vidensinstitution

fra "modtagere" til partnere

virksomhed

Figur 1: ELYK-projektets triple helix-model.

Nu bliver disse i hver deres domæne aktivt handlende subjekter (hhv: brugere, "prosumere", og deltagere) (Figur 1). I modellen er brugeren en konstruktion, der tilskrives mening i det enkelte domæne, men samtidig et samlingspunkt for de forskellige rationaliteter og perspektiver. Samstemt og dynamisk i forhold til denne ændrede rolletilskrivning udvikler relationerne sig mellem de forskellige domæner: Myndighedernes tidligere myndighedsudøvelse (regulering) garneret med lidt erhvervsfremme transformeres nu til en samlet indsats for at gøre virksomhederne konkurrencedygtige og innovative i forhold til en global dagsorden, sådan som det $\mathrm{f} x$ afspejles $\mathrm{i}$ formuleringerne fra de forskellige globaliseringsinitiativer. Relationen mellem vidensinstitutioner og virksomhed transformeres fra, at "skolen" skal levere kvalificeret arbejdskraft, til partnerskaber hvor læring og innovation bliver et fælles anliggende. Endelig bliver myndighedernes relation til vidensinstitutionerne også et anliggende for udvikling og diskussion, hvor de tilskrives mere autonomi, men samtidig også underkastes mere styring i form af output kontrol.

Brugeren bliver en kode som muliggør mødet. Den overordnede pointe er, at der foregår en udvikling, i rationalitet såvel som i form, i relationerne 
mellem myndigheder, vidensinstitutioner og virksomheder. Denne udvikling kan ses som en styrkeprøve mellem forskellige rationaliteter og som en forhandling af, hvordan nye udfordringer skal tages op. Relationerne er så at sige medieringer af strukturelle koblinger de forskellige systemer imellem. Ud fra dem er det muligt at diskutere, hvordan møder og konstruktioner opstår, og dermed er der et analytisk udgangspunkt for at forstå kreativitetens og innovationens rationaler på et systemisk niveau.

\section{Design-overvejelser}

Ovenfor har vi forsøgt at skitsere, hvorledes relationerne mellem forskellige domæner redefineres i forbindelse med overgangen fra industrisamfund til globaliseret konkurrencestat. "Brugeren" bliver her det konceptuelle mødested, hvor aktørernes forskellighed forsøges indfanget med henblik på at skabe udvikling og innovation. Denne innovation skal netop skabes, formgives og meningstilskrives. Den skal designes, og det gælder også læremidler og læring.

\section{Didaktisk Design?}

Det er blevet populært at tale om didaktisk design - altså formgivning af læring. Snævert betragtet er begrebet meningsløst, idet didaktik pr. definition er en formgivning af og refleksion over formgivning af læreprocesser. Formel læring, sådan som vi kan iagttage den i uddannelsessystemet, er dermed betinget af og et udtryk for udlægningen af et mere eller mindre artikuleret og reflekteret didaktisk design, og dermed er den undervisningsbaserede læring altid et produkt af et didaktisk design. Begrebet karakteriserer således ikke didaktik som begreb, men snarere at den didaktiske proces er underkastet nye og ændrede betingelser: Betingelser, der kort opsummeret vedrører såkaldte nye medier, ændrede kompetencebehov og videre de ændrede forventninger fra de lærendes side. Vi kan folde det lidt mere ud og sige, at vi i dag har medier som sætter den lærende i stand til både at få adgang til viden, dele viden og udvikle viden i et omfang, som ikke tidligere er set. Uddannelsessystemet stilles parallelt over for et krav om, at den lærende ikke alene skal tilegne sig den viden som er, men også udvikle kompetencer til både at udvikle ny viden og bruge denne viden i praksis. Endelig har vi en lærende (elev, studerende eller måske en deltager, sådan som den lærende ofte karakteriseres i en voksenpædagogisk diskurs), der ikke længere stiller sig tilfreds med at få lov til at modtage undervisning, men forholdsvis artikuleret stiller krav om, at de læreprocesser, som vedkommende indgår i, skal være oplevelses-, menings- og nyttefyldte. Med forskellige fordelinger af disse forventninger udspilles didaktisk design (som vi vælger at kalde det) dermed i et krydspres af forventninger og muligheder, der ikke tillader repetition og gentagelse, men påberåber 
sig både en nærværende undervisning og et dynamisk curriculum, som didaktik og undervisning kan lade sig inspirere af, men som samtidig ikke må være en begrænsning, der indskrænker mulighederne for ny- og gentænkning. Det didaktiske design er således et udtryk for et vedblivende og samtidig intensiveret og distribueret krav om formgivelse, hvor den traditionelle, forskudte didaktiske proces i sin konkrete udformning (forstået som uddannelsesstyring der angiver uddannelsesplanlægning, som igen angiver undervisningsplanlægning) både mister sin hierarkiske struktur og gen-introducerer den med krav om målbarhed. Det skal forstås på den måde, at design af og iværksættelse af læreprocesser i dag på den ene side er frigivet fra overordnet specifik bestemmelse, men samtidig er underkastet krav om målbarhed. Det er tilfældet i det pædagogiske møde i undervisningen. Det er også tilfældet i forhold til uddannelsesinstitutionernes strategiske beslutninger og handlinger.

Uddannelsessystemets anliggende er læring; uddannelsessystemets midler er formgivning, herunder indholdsbestemmelse af undervisningen. Denne formgivning, dette design, åbnes nu for flere aktører - først og fremmest for brugerne. Det sker for at skabe mere relevante former, knytte tættere mellem deltagernes forudsætninger og præferencer, og ikke mindst for at dette potentiale ikke må henligge uopdyrket.

Udfordringen er naturligvis at skabe former, hvor disse potentialer kan mobiliseres, idet den lærende eller innovative her skal bidrage med noget, vedkommende ikke ved eller kan. Den lærende er netop lærende, i og med han eller hun ikke kan netop dette. Hvis vedkommende kan det, er der jo ingen grund til at lære det. Hvis vedkommende ikke kan det, hvordan kan det så artikuleres? Kan vi formulere det, vi ikke ved? Det er netop underviserens rolle, men det bliver også udviklerens rolle i innovationsprojekter. Det er den samme udfordring, vi har i forbindelse med brugerdreven innovation, der er potentialer for ny praksis i praksis. Med det oprindelige græske begreb så er praksis netop kendetegnet ved, at deltagerne er hensunket i og opslugt af denne. I modsætning hertil har vi iagttagelsen, på græsk teorien, der giver mulighed for blikforskydning. Det er netop den blikforskydning, som ifølge Platon (2005) giver mulighed for læring og forandring.

Det er i sin essens vores anliggende her. Vi må bygge videre på den viden, der er i praksis. Det er typisk ikke en artikuleret viden, men en latent viden. Derfor har vi brug for det fremmede, iagttagelsen, der igen kan indgå i genkonstruktion af praksis. Den ydre iagttagelse af en praksis (et særligt felt) giver anledning til en systematisk bestemmelse af fænomener i feltet, men denne skal så oversættes til en for praksis forståelig optik. Her er netop begrebet optik på sin plads, idet vi skal give mulighed for, at disse iagttagelser kan genindskrives i praksis gennem en reflekteret, men ikke refleksiv selviagttagelse. Refleksionen sker på basis af iagttagelserne, der 
måske er oversat til en prototype. Denne prototype er vores oversættelse fra en iagttagelse til en mulighed. Iagttagelsen, teorien om praksis, er netop generel, men gennem oversættelsen til prototypen bliver den igen partikulær, hvorved den bliver en mulighed, som feltet kan bruge som afsæt for selviagttagelsen. Giver denne prototype mening i vores sammenhæng, hvordan kan vi forstå den, hvilke ændringer skal den gennemgå, hvis den skal indgå i vores fremtidige praksis - og hvordan vil vores praksis ændre sig, hvis den indgår?

\section{Design?}

"The ultimate object of design is form."(Alexander, 1964)

Med dette citat fra design-teoretikeren Christopher Alexander tillader vi os at åbne en diskussion af forholdet mellem brugerdreven didaktisk design og brugerdreven udvikling af læremidler og didaktiske designs. Design er et trefoldigt begreb, i og med at det for det første skal kunne begribe en verden. For det andet skal vi kunne skabe form på denne fornemmelse eller begribelse. For det tredje handler det om at kunne skabe mulighed for meningstilskrivelse i denne formsættelse. Det er dermed både en ydre og en indre proces. Designeren skal kunne analysere og fornemme, hvad det for kræfter, der er på spil her. Videre skal vedkommende kunne skabe en form, der giver det, design-teoretikere ville kalde "et fit" - ikke mellem en eksisterende praksis, men mellem en ny form og en potentiel ny praksis, hvor denne form vil indgå og samtidig være den eller en af de kræfter, der transformerer denne praksis eller kontekst (Alexander, 1964). Hvor man så videre kan sige, at denne kontekst ikke er en statisk størrelse, men er under stadig konstruktion. Designet af gode læreprocesser er forståelse af de kræfter, der er på spil, og formgivning i forhold til dem. "Kræfterne" er Alexanders begreb, hvor det udtrykker en søgen efter det, der er på spil i praksissen. I vores sammenhæng sker denne kortlægning af "kræfterne" både i de indledende iagttagelser af feltet, og også i genindskrivningen gennem anvendelsen af prototyperne, som medier for feltets selviagttagelse og artikulering.

Arbejdet med design skaber behov for at udvikle en tilgang, der medtænker og mobiliserer forskellige tilgange - og også forskellige kompetencer hos de involverede. Over tid viser det sig, at der ikke alene er tale om udviklinger af tilgange og metoder, men også om en ny tænkning, hvor der er fokus på, hvordan der kan skabes noget nyt og bedre. Denne designtænkning er således en del af projektets udvikling. Det er et forhold, som andre også har iagttaget. Design-tænkningen er et begreb, der er opstået i forbindelse med udbredelsen af designernes virke til andet end den ydre form på dette eller hint produkt (Brown, 2008). Sigtet er her at skabe produkter og processer, hvor mennesket og et bedre liv er i fokus. men 
også at selve processen er "deeply human" (Brown \& Wyatt, 2010). Hvor udviklerne eller designerne skal have kompetencen til at forstå mønstre og udvikle idéer, der både er meningsfyldte, taler til følelserne og samtidig er funktionelle. Her genfindes de tematiseringer som vi præsenterede oven for: at design ikke er et éntydigt rationelt anliggende, men eksplorativt, hvor forskellige modi supplerer hinanden. Det er en proces, hvor det emotionelle og intuitive også spiller en afgørende rolle. Det er ikke mindst tydeligt, når vi taler om didaktisk design, hvor anliggendet netop er mennesker og at ville noget med disse mennesker; og hvor dette ikke alene skal være funktionelt ud fra et snævert læringsmæssigt perspektiv, men også skabe attraktion og motivation, hvorved det naturligvis også bliver funktionelt.

Når den didaktiske design-proces foldes ud, kan alt ikke indfries på én gang. I ELYK-projektet har vi derfor arbejdet i den såkaldte Firefelt-model, som netop angiver, at vi i en sådan proces har forskellige positioner: den iagttagende og den deltagende. Brown \& Wyatt beskriver dette forhold på følgende måde:

\section{The design thinking process is best thought of as a system of overlapping spaces rather than a sequence of orderly steps." (Brown \& Wyatt, 2010).}

I vores version indgår disse elementer også, men vi har her et tydeligere fokus på selve designet af disse rum, og hvilke positioner de definerer og også udfordrer. Brown \& Wyatt har her samme iagttagelse, som vi fremlægger oven for, nemlig at det er et begrænset udbytte, der opnås, hvis brugerne spørges. De fremhæver, at hvis vi skal basere os på at spørge, hvad brugerne ønsker, så fastholdes vi i begrænsede eller "inkrementale" innovationer. Brown og Wyatt, der er aktive i et designbureau og ikke er forskere, unddrager sig her en vigtig bekymring, som vi har måttet have: Hvordan sikres en forskningsmæssig position i denne konstruktion? Den forskningsmæssige dimension bliver her forandret. Almindeligvis skal en forsker holde en distance til feltet for at skabe mulighed for generalisering. Men her pendler forskeren mellem forskellige positioner - eller for at bruge et Luhmann-begreb: oscillerer mellem positioner. Det er ikke et problem, men en særlig udfordring, at forskeren både er iagttagende og deltagende, at han eller hun selv er medskaber på sit forskningsobjekt. Styrken ved denne fremgangsmåde er, at forskeren kan bruge denne flerhed af positioner til at skabe en dobbelt iagttagelse, hvor han ved at anlægge flere perspektiver kan kvalificere den introspektion, der altid bør være en del af en god forskningspraksis. Det er denne dobbelte optik, som vi populært har tematiseret som udvikling gennem forskning og forskning gennem udvikling: Dermed lægger denne tilgang sig op ad designbaseret forskning, hvor sigtet er at skabe forskningsmæssig validitet gennem 
designeksperimenter og samtidig sikre, at det, der sker, har betydning for de øvrige involverede parter. Samtidig er den også relateret til aktionsforskning, der i sine forskellige udgaver med forskellige vægtninger også forsøger at skabe både udvikling og forskningsmæssige resultater. Vores tilgang adskiller sig imidlertid fra disse skoler ved systematisk at skifte perspektiv og vedholdende at forsøge både at definere og udvikle innovationsperspektivet.

\section{Firefelt-modellen}

At brugeren er en konstruktion er en afgørende pointe i den model for brugerdreven innovation, som har været anvendt på tværs af alle ELYK's delprojekter. Dens styrke er netop, at repræsentanter for alle kategorier af aktører (myndigheder, virksomheder, vidensinstitutioner og ikke-ekspert borgere) i fællesskab og med udviskning af konventionelle roller indgår i innovationsprocesser, hvor de emergerende produkter fungerer som grænseobjekter mellem de forskellige aktørgruppers vidensystemer - altså de domæner som vi beskrev ovenfor.

Design-modellen tager afsæt i og forsøger at kombinere tre ret forskellige design-traditioner. En af dem er brugerinddragende design (Participatory Design) traditionen, som den er udfoldet i den såkaldte skandinaviske design-skole, hvor det at fremstille artefakter også indebærer at integrere dem i en praksis-kontekst (Ehn \& Kyng, 1987). En anden tradition er bruger-innovation som for eksempel beskrevet af Eric von Hippel (2005), hvor "brugerens stemme" (afdækning af brugerbehov) kombineres med "spydspidsbrugeres" deltagelse i at frembringe nye produkter. Og endelig er der hentet inspiration i design-based forskning inden for uddannelse, hvor brugerne deltager som design-partnere (Barab \& Squire, 2004; Amiel \& Reeves, 2008).

I forbindelse med ELYK-projektet blev der udviklet en model for brugerdrevet innovation. Den oprindelige model, Firefelt-modellen (Helms, 2009; Helms \& Heilesen, 2011), er et forsøg på at forstå og samtidig strukturere forskellige positioner og roller i en innovationsproces (Figur 2). Udgangspunktet er, at når brugeren er en konstruktion (jf. ovenfor), samt når det kan være ganske vanskeligt initialt at identificere endsige forløse innovationspotentialer i praksis, så kan det give god mening at bevæge sig fra en situation, hvor forskeren blot observerer og udforsker feltet til en, hvor brugerne aktivt deltager i observationen, og videre til en situation hvor brugeren bliver partner, og slutteligt til en ny situation, hvor innovationen bliver en del af (en ny) praksis. Tanken er således, at de forskellige positioner styres af forskellige rationaliteter og metoder, som så igen kræver en mere generel metodediskussion. 


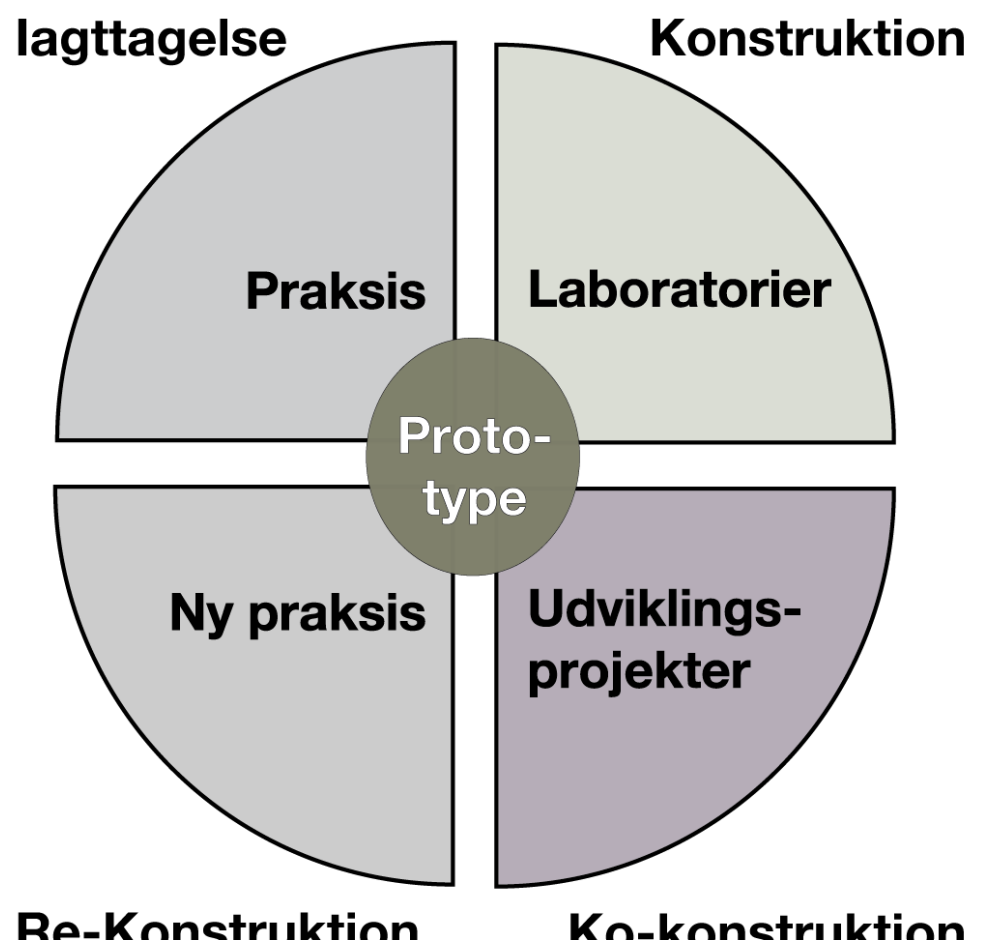

Figur 2. Firefelt-modellen.

I modellens øvre venstre felt (Iagttagelse) er markeret den nuværende praksis (Figur 2). Når der skal udvikles nye produkter, er det naturligvis nødvendigt at være fortrolig med eksisterende praksisser samt de sammenhænge, innovationen skal indgå i, og hvem slutbrugerne er. Sådanne indledende observationer kan fx udføres vha. etnografiske metoder. På dette stadie er innovatorerne (dvs. forskerne) de iagttagende, og brugerne er de iagttagede.

I det Øvre højre felt, Konstruktion, bliver nye artefakter udviklet og afprøvet. Der er ikke tale om et bestemt fysisk sted, men om en ramme for afprøvning af prototyper sammen med brugerne, samt om idégenereringsøvelser med forskellige brugergrupper om nye potentialer. I ELYK-projektet har laboratoriet typisk haft form af workshops, hvor initiativtagerne (forskerne) lægger deres første resultater frem til diskussion med brugerne, og hvor alle deltagere bidrager med at udtænke prototyper for nye praksisser. I laboratoriet bliver brugerne artikulerede aktører, mens forskerne skifter rolle fra observatører til (med-)udviklere.

Ko-konstruktion, i nedre højre felt, er der, hvor prototyperne (videre)udvikles og afprøves. I projektet bidrager samtlige deltagere med deres forskellige rationaliteter og kompetencer. De oprindelige roller omdefineres til et 
partnerskab, som ikke er defineret af position (iagttager - iagttaget) men af kompetencer.

Endelig udfoldes de nye praksisser i feltet for neden til venstre ( $R e$ konstruktion). På dette stadie transformeres innovationen til en del af organisationens hverdag. Hvis det sker, udviskes teknologiaspektet, idet teknologien blot bliver en del af praksis. Den trækker sig tilbage fra opmærksomheden og bliver en del af det, "man" gør. Modellen skal ses som en spiral, hvorfor denne fase vil være afsæt for nye innovations-iterationer.

\section{Metadesign-modeller}

ELYK-innovationsmodellen, eller Fire-feltmodellen, kan karakteriseres som en metadesignmodel. Det vil sige en overordnet model, som skal kunne håndtere en række skiftende brugs- og designprocesser, hvor netop brugs- og designprocesser er overlappende og afhængige af perspektivet. Begrebet meta-design er under udvikling og angiver behovet for at kunne håndtere komplekse design-situationer, hvor flere fagligheder er nødvendige, og hvor roller skifter over tid (Giaccardi \& Fischer, 2008). I ELYK-projektet har vi således været inspireret af og taget afsæt i modeller for "participatory design", hvor brugerne spiller en afgørende rolle, men vi har også påvist, hvordan brugeren redefineres i processen. Det er her af afgørende betydning at have en struktur og en proces, der kan eksplicitere dette og understøtte den sensemaking (Weick, 1979), der er nødvendig i forhold til integrationen af projektet i aktørernes praksis.

Metadesign er et design af design, som skal kunne håndtere ikke blot designsituationen, men design-situationerne, hvorved det angives, at designet skabes over tid og over rum. I traditionelle designpraksisser skelnes der mellem "designtid" og "brugertid". Almindeligvis med den tidsdimension, at først har vi designtid, derefter brugertid; hvor der så i participatory design tilføres faser, hvor brugerne involveres for at sikre, at det udviklede sker i overensstemmelse med deres behov og ønsker. I metadesign-tilgangen er der tale om forskellige perspektiver, som udvikler sig og udvikler sig gensidigt over tid: Hvor netop de forskellige perspektiver ses som muligheden for at skabe udvikling. Det er ikke et praksisfællesskab i den Wengerske betydning, idet der hos Wenger (1998) er tale om et fælles anliggende(r). I ELYKprojektet er der tale om forskellige anliggender, der kun forenes af et forholdsvis overordnet perspektiv om både pædagogisk og erhvervsmæssig udvikling. For den enkelte aktør er perspektivet nytte i et specifikt perspektiv, hvor selve idéen om brugerdreven innovation er, at der dermed kan skabes mere relevante former. Det kan være en bedre måde at lave netbaseret undervisning for ledere eller støtte til regional erhvervsudvikling. ELYKinnovationsmodellen forsøger at transcendere disse perspektivforskydninger, idet faseopdelingen tillader sense-making, der udvikler sig 
over tid. Det vil sige, at der i den indledende fase opereres med: Det vi ikke ved, at vi ved. Altså en artikulering af den tavse viden i en praksis med en angivelse af potentialer. Oversættelsen af disse iagttagelser til prototyper i design-modellens fase to giver mulighed for at arbejde med Det vi ikke ved, at vi ikke ved. Det vil sige, at praksis her selv oplever potentialet i ny viden. I projekt- og udviklingsfasen arbejdes der videre i forhold til Det, vi endnu ikke ved, at vi ikke ved, men som udvikler sig i forløbet. I overgangen til praksis sker der så endnu et perspektivskifte til det, vi ikke længere ved, men kan. Teorier og modeller har dog samtidig haft stor betydning for de forskellige aktører.

Modellerne er en del af den reificering eller artefakt-gørelse, der gør, at der kan tales om processerne. Den norske aktionsforsker Øyvind Pålshaugen skriver om sådanne teorier og modeller i forholdet mellem praksisser:

\begin{abstract}
"At det er her, vi finder en hemmelig kommunikation mellem praktiker og teoretiker. Begge ved, at det er en illusion at tro, at modellen afspejler virkeligheden. Men samtidig kan vi ikke lade være med at være fascinerede som af en god film, selvom vi ser det som en leg, en illusion, på samme måde kan vi ikke lade være med at være fascinerede af en god teori. - Og det er netop som teori, at den er fascinerende. Modellerne af organisationsteorierne giver netop muligheden for "play with realities". Det er på samme tid en måde at tænke på organisationens realitet og en organiseret måde at lege med en idé."

(Pålshaugen, 1998, p. 12, vores oversættelse).
\end{abstract}

Teorierne og modellerne indgår således som måder, vi kan konstruere og nykonstruere virkeligheden. Mødestedet mellem teoretiker og praktiker er dermed ikke praksis, men de forskellige billeder af praksis. Eller som Pålshaugen beskriver det, så:

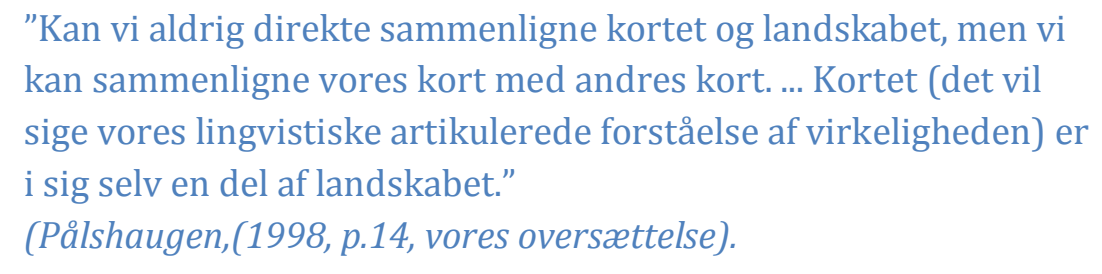

I ELYK-projektet har fx Firefelt-modellen (eller ELYK-innovationsmodellen) indgået i udviklingsgruppernes konstruktion af nye sociale virkeligheder. Den har også været en del af måden at forstå workshops og processer på. Udfordringen er at skabe former, som kan overskride praksisser, hvorved det fremmede bliver en del af aktørernes læring. Risikoen kan være, at 
translationen bliver at finde en fællesnævner, som på sin vis fastholder asymmetriske videnformer. Det kan fx være, at der er en gensidig overenskomst mellem de forskellige parter om, at vi finder en model, der giver mulighed for at fortsætte den nuværende praksis, men med en digital komponent, hvor de kompetencemæssige potentialer ikke indfries, fordi dette fx ville kræve organisatoriske ændringer.

\section{Mikro-niveau: Interessefællesskaber}

Det praktiske metodiske arbejde i de forskellige ELYK-delprojekter har omfattet dokumentstudier, interviews, spørgeskemaundersøgelser, observationer, logfil-analyser og workshops. Af disse metoder har workshops med forskellige brugergrupper været de mest givende og i en udviklingssammenhæng metodisk interessante.

Workshops kan anskues som særlige, midlertidige fællesskaber. De er ikke fællesskaber i en Lave \& Wenger (1991) forstand, men er friere og karakteriseret ved forskelle snarere end ensartethed. Fra start er deltagerne indlejret i forskellige domæner, men i løbet af processen bryder de ud af dem, samtidig med at de repræsenterer dem, og mødes om udfordringen i at udvikle nye ideer og produkter. Uvantheden og udfordringen, som nok tolkes forskelligt i forskellige domæner, nødvendiggør en begrebsliggørelse, som er forskellig fra "praksisfællesskaber". I ELYK-udviklingssammenhængen er det måske mere dækkende at tale om interesse-fællesskaber ("Communities of Interest”, Fisher, 2001). Interessefællesskabet er et fællesskab af fællesskaber, hvor interessenter fra forskellige fællesskaber mødes. I vores optik er det en både adækvat og operationel model for, hvordan interaktion foregår i nye videnregimer.

Der frembringes en situation, hvor forskellige domæner mødes, ikke fordi de deler rationalitet, men fordi de er forenet i en vision om eller interesse for nyskabelse gennem forskellighed. Det har været en kerneopgave i ELYKprojektet at facilitere sådanne situationer, hvor aktører og interessenter fra forskellige domæner i fællesskab udvikler ny viden. Men for at det skal lykkes, er det vigtigt, at fællesskaberne forbliver midlertidige og at de ikke ender med at blive homogene. Der skal være en strukturel vekslen mellem åbenhed og lukkethed, og der tilstræbes mange-faglighed snarere end en tværfaglighed, som let fører til, at der fokuseres på det fælles.

Når aktørerne samarbejder i en innovativ kontekst i snitfladen mellem forskellige domæner, er der behov for materialitet eller medierende artefakter. Fisher fremhæver behovet for grænseobjekter, som skaber mening på tværs af vidensystemer. De skaber netop ifølge ham en fælles referenceramme, som giver mening inden for flere systemer, men som samtidig tillader både forskellige fortolkninger og forventninger til 
resultater. Dermed bliver den indledende "symmetri af uvidenhed til ressourcer for læring og social kreativitet (da innovationer kommer udenbys fra)." (Fisher, 2001; forfatternes oversættelse).

I teorier om praksisfællesskaber ville man tale om relationen mellem reifikationer (tingsliggørelser) eller medierende artefakter. Kernen i Wengers (1998) teori er netop, at vi lærer ved at blive en del af et fællesskab, og at denne "bliven" repræsenterer en dobbelt proces med reifikation af deltagelse. Da reifikationer stabiliserer processen, bruger vi reifikationer som en hjælp til forståelse og ikke som en retningsanvisning. I midlertidige innovationsfællesskaber bliver reifikationerne ustabile, og de ændres både gennem skift i deltagernes forståelse af dem og gennem udviklingen af selve eksternaliseringen.

De bliver på den måde såkaldte sociale objekter, som er kendt fra sociologien fx fra Mead og i nyere tid især Ralph Stacys gentænkning af netop Mead (Stacy, 2005). Mens vi med grænseobjekter sætter særligt fokus på, hvordan sådanne reifikationer skal forstås i relationerne mellem forskellige kontekster.

Udtrykket kan føres tilbage til Star og Griesemers (1989) undersøgelse netop af, hvordan der skabes sammenhæng på tværs af forskellige sociale verdener. Her udfoldes betydningen af sociale objekter:

“Grænseobjekter er objekter, der er plastiske nok til at kunne
tilpasses til lokale behov og de begrænsninger, som karakteriserer
de forskellig aktører, der bruger dem, men samtidig robuste nok til
fastholde en fælles identitet på tværs affælles lokaliseringer. De er
svagt strukturerede i en generel betydning, men bliver stærkt
strukturerede når de bruges af den enkelte. Disse objekter kan
være både abstrakte og konkrete. De har forskellig mening i
forskellige sociale verdener, men deres struktur er åben nok til at
være genkendelig som et middel til translation. Skabelsen og
håndteringen af grænseobjekter er en nøgleproces i forhold til at
skabe udvikling og sammenhæng på tværs af sociale verdener.”
(Star \& Griesemer, 1989; forfatternes oversættelse).

Det er netop denne sammenhæng på tværs af forskellige kulturer, sociale skel og rationaliteter, der konstituerer udviklings- og innovationsfællesskaber.

\section{Læringsperspektivet}

I ELYK-projektet er det tydeliggjort, at deltagelse i innovationsfællesskaber giver mulighed for både læring og meningsfyldt udvikling af læringsteknologi. Det er læreprocesser, hvor deltagerne arbejder i "design mode", hvor vi med de canadiske uddannelsesforskere Bereiter \& Scardamalia (2003) er optaget af: "... brugbarheden, det hensigtsmæssige, 
forbedringsmulighederne og udviklingsmulighederne i en idé" (forfatternes oversættelse). I uddannelsessammenhænge arbejder vi sjældent i dette modus, men det er i kombinationerne af at være i dette modus og i andre modi, at udviklings- og innovationsmulighederne ikke mindst ligger.

Hvis vi skal koble fra det didaktiske design til nogle mere generelle principper for en videre udvikling af en voksenpædagogisk praksis, så kunne det være:

- Udvikling af en "levende" læreplan, der både udfordrer og skaber retning i forhold til den lærendes læring i emergerende fænomener,

- Strukturer, der understøtter bevægelsen fra styring til autonomi,

- Skift mellem forskellige læringskontekster og tydelige markører af, hvad der kan læres og hvor,

- Involvering af den lærende som fuldgyldig aktører i fx udviklingsprocesser,

- Flerfaglig læring mellem forskellige fag og i udviklingsgrupper på tværs af uddannelser,

- Evaluering, hvor både den skolastiske og den virksomhedsknyttede viden værd- og værdisættes af aktører fra de relevante domæner.

\section{Referencer}

Alexander, C. A. (1964), Notes on the Synthesis of Form, Cambridge, MA: Harvard University Press.

Amiel, T. \& Reeves, T. C. (2008). Design-Based Research and Educational Technology: Rethinking Technology and the Research Agenda. Educational Technology \& Society, 11 (4), 29-40.

Anderson, T. \& Dron, J. (2011). Three generations of distance education pedagogy. International Review of Research in Open and Distance Learning 12(3; Special Issue: Design and Delivery of Social Networked Learning), 81-97. Retrieved January 26, 2012, from http://www.irrodl.org/index.php/irrodl/article/view/890.

Arnkil, R., Järvensivu, A., Koski, P., \& Piirainen, T. (2010). Exploring the Quadruple Helix. Report of Quadruple Helix Research for the CLIQ Project. Tampere: Work Research Centre, University of Tampere.

Barab, S. \& Squire, K. (2004). Design-Based Research: Putting a Stake in the Ground. Journal of the Learning Sciences, 13(1), 1-14. 
Bereiter, C. \& Scardamalia, M. (2003). Learning to work creatively with knowledge. In E. De Corte, L. Verschaffel, N. Entwistle, \& J. van Merriënboer (Eds.), Powerful learning environments: Unraveling basic components and dimensions (pp. 55-68). (Advances in Learning and Instruction Series). Oxford, UK: Elsevier Science.

Brown, T. (2008). Design Thinking. Harvard Business Review, June, 1-10. Retrieved February 27, 2012, from http://www.unusualleading.com/wp-content/uploads/2009/12/HBRon-Design-Thinking.pdf.

Brown, T. \& Wyatt, J. (2010). Design Thinking for Social Innovation. Stanford Social Innovation Review 8(1), Publisher: Stanford University Graduate School of Business, Pages, 30-35.

Clausen, L. (2010). Mediebrud mellem organisationer og netværk [Media disruptions between organisations and networks]. MedieKultur. Journal of Media and Communication Research, 26(49), Retrieved January 5, 2012, from http://ojs.statsbiblioteket.dk/index.php/mediekultur/article/view/236 9/3378.

Ehn, P. \& Kyng, M. (1987). The collective resource approach to system design. In G. Bjerknes, P. Ehn \& M. Kyng (Eds.), Computers and Democracy - a Scandinavian Challenge (pp. 17-57). Avebury: Aldershot.

Etzkowitz, H. (2002). MIT and the rise of entrepreneurial science. London: Routledge.

Heilesen, S. B., \& Helms, N. H. (2010). Om kommunikationspraksis i nogle danske erhvervsnetværk (ELYK Working Paper 5). Roskilde: Knowledge Lab. Retrieved February 14, 2012, from http://elyk.dk/wpcontent/uploads/2011/09/ELYK-Workingpaper-5.pdf.

Fischer, G. (2001). Communities of interest: Learning through the interaction of multiple knowledge systems. In Proceedings of the 24th Annual Information Systems Research Seminar in Scandinavia (IRIS'24) (pp. 1-14). Ulvik.

Giaccardi, E. \& Fischer, G. (2008). Creativity and evolution: a metadesign perspective. Digital Creativity 2008, 19(1), 19-32.

Heilesen, S. B. \& Helms, N. H. (2011). Netværk og klynger online - en midtvejsstatus (ELYK Working Paper 5). Odense \& Roskilde: Knowledge Lab. Retrieved February 14, 2012, from http://elyk.dk/wpcontent/uploads/2011/09/ELYK-Working-Paper-4.pdf. 
Heilesen, S. B. \& Helms, N. H. (2012). Nye teknologimedierede klyngeformer (ELYK Rapport 10). Odense og Roskilde: Knowledge Lab. Retrieved February 14, 2012 http://elyk.dk/wpcontent/uploads/2011/09/ELYK-forskningsrapport-10Teknologimedierede-klynger-130212.pdf.

Helms, N. H. (2009). Is there such a thing as Tech Trans? Or learning from Pasteur. Working Paper from the Bonita Project. Retrieved February 14, 2011, from http://www.bonita-project.eu/papers/A01TechTrans/.

Hippel, E. v. (2005). Democratizing innovation. Cambridge, Mass.: MIT Press.

Lave, J., \& Wenger, E. (1991). Situated learning : legitimate peripheral participation. Cambridge [UK]; New York: Cambridge University Press.

Platon (2005). Menon, Oversat og kommenteret af Chr. Gorm Tortzen. Retrieved June 14, 2012, from aigis.igl.ku.dk/2005,1/CGTMen.pdf

Pålshaugen, Ø. (1998). The end of organization theory: language as a tool in action research and organizational development. Dulles [VA]: John Benjamins Publishing Company.

Siemens, G. (2005). Connectivism: Learning as network-creation. ElearnSpace. Retrieved January 26, 2012, from http://www.elearnspace.org/Articles/networks.htm.

Siemens, G. (2006). Knowing Knowledge. Retrieved January 26, 2012, from http://www.elearnspace.org/KnowingKnowledge_LowRes.pdf.

Stacey, R. D. (2005). Experiencing emergence in organizations: Local interaction and the emergence of global pattern. London: Routledge.

Star S.L. \& Griesemer J.R. (1989). Institutional Ecology, 'Translations' and Boundary Objects: Amateurs and Professionals in Berkeley's Museum of Vertebrate Zoology, 1907-39. Social Studies of Science 19(4), 387-420.

Weick, K.E. (1995). Sensemaking in Organizations, Thousand Oaks [CA], London: Sage Publications.

Wellman, B. (2002). Little Boxes, Glocalization, and Networked Individualism. In M. Tanabe, P. v. d. Besselaar \& T. Ishida (Eds.), Digital Cities II: Computational and Sociological Approaches (pp. 11-25). Berlin: Springer-Verlag.

Wenger, E. (1998). Communities of Practice: Learning, Meaning, and Identity. Cambridge: Cambridge University Press. 
